\title{
Start-ups, bearers of innovation in globalizing environment and their valuation
}

\author{
Veronika Achimská, ${ }^{1, *}$ \\ ${ }^{1}$ University of Zilina, Faculty of Operation and Economics of Transport and Communications, \\ Department of Communications, Univerzitna 8215/1 Zilina, Slovakia
}

\begin{abstract}
The paper presents chosen methods of star-up valuation. In the context of globalization, innovations are clearly bearers of a potential enterprises' competitiveness, start-ups are consider as their most important sources. Start-ups are mainly based on the human capital designed to create novel products, services, processes, and bring them to the markets. The basic precondition for meaningful growth of start-ups is favourable business environment (legal and administrative point of view) and framework supporting innovative entrepreneurship including access to external sources of financing. Start-ups are investments with a significant degree of uncertainty, lacking any characteristics pointing to their financial and economic performance from a historical perspective, which restricts the use of "traditional" business valuation methods. It should also be pointed out that, as there is no uniform valuation for maturity enterprises, there is no uniform procedure for valuing of a business even in the case of start-ups. The presented approaches take into account decisive criteria of start-ups, including a life cycle of a start-up in which an investment is made, and other factors affecting valuation. Their use from a theoretical point of view is generalized, the practical use is already determined by specific conditions under which the valuation takes place.
\end{abstract}

\section{Introduction}

The valuation process of any firm is a complex issue, because of the diversity of factors quantitative and qualitative nature that come into account during valuation [1]. Valuation, fundamentally, remains the same, no matter what type of firm is being analysed, however valuing a start-up is much more complicated and estimates of its value more noisy [2]. The reason is that, in generally, valuation is based on three core pillars of information: financial statements, history of a firm mainly in terms of market share, market prices and revenues, and information on comparable firms. Information of this nature is considerably curtailed for start-ups. Except that, they usually do not have significant investments in fixed assets, which does not mean that start-ups do not have any value, even though a significant degree of uncertainty exists in valuing. An important turning point is the moment of time, when the future development of a start-up becomes highly addicted to external investors, so it is expected that the knowledge of the value be justified. An equity gap, typical mainly for

\footnotetext{
* Corresponding author: veronika.achimska@fpedas.uniza.sk
} 
start-up firms, is the second most common reason for a start-up failure [3]. Hechavarría et al. states that external financing in case of start-ups supports their further development and in comparison to start-ups financed mainly by the owner's sources, they reach the maturity phase much faster [4]. Except that, firms financed by external equity less likely leave the market than firms with lower or no external capital do. External investors divided usually into FFF investors, backers within crowdfunding, business angels, venture capitalists, and private equity investors orient their investment in different development stages of the startup firm. The start-up financing cycle is linked to the development cycle of a business idea or cycle of the start-up firm development. Each stage of development is different and needs different financing solutions. Investors purposefully differentiate individual stages of startup and consider the size and risk of investment accordingly [5]. They base decisions on different frameworks, which identification is in the middle of interests of researchers and practitioners (e.g. Fried and Hisrich, 1994; Paul, et al., 2007; Van Osnabrugge, 2000, Zinecker - Rajchlová, 2010 etc.) [5-8]. In the earliest stages (idea stage, seed stage), needed finance for the start-up development come mainly from the owners, FFF investors, crowdfunding sources, and business angels. The last group of investors are typical investors specialized on start-up financing. According to e.g. Van Osnabrugge - Robinson, Sudek etc. business angels do not perform any due diligence or less professional in comparison to venture investors, rely rather on instincts, and invest more opportunistically $[9,10]$. The personality of entrepreneur, innovation of idea, and management team of the start-up (in general human potential) are the primary factors influencing their involvement in financing. The first groups of external investors base their investment decisions rather on personal relationships with an entrepreneur than only on assessment the potential of the start-up [11]. Thereby we assume that then the following development stages (start-up and expansion stage) and financing cycle of the start-up (start-up capital, expansion capital, acquisition capital, debt replacement capital, in some cases also rescue capital) will be decisive for applying sophisticated approaches to start-up valuation.

The main aim of the author is to present the chosen methods of valuation that are suitable for start-ups in the earliest stage of their development from the theoretical point of view. The first precondition is to define the term "start-up" and other resulting facts that based on several authors restrict the use of traditional business valuation method. In the context of the article, traditional valuation methods are considered to be income-based methods, which are based on the principle of discounting cash flows and the equity method. Other start-up valuation methods are alternative approaches, and have generally been developed in the context of the start-up's life cycle.

\section{Definition of term "start-up"}

There is no permanent and conventional definition of the term "start-up". Commonly used definitions either highlight specific features of such kind business or generally present it as a new business - an early-stage firm without any needs to point its specifics. The general definition offers e.g. the OECD (2016) that considers a start up as a newly born firm or firm that is no more than two years old without any other specifications. However, there are prevailing views across the public that the start-up is a firm that is a bearer of innovations and thanks to them is able to meet needs of customers better and more effectively than "normal" firms are or is a creator of new needs that concurrently also satisfies. The most of definitions perceiving the start-up in a stricter sense. They consider it a specific business model working under conditions of extreme uncertainty (e.g. Peemöller et al., 2001, Blank - Dorf, 2014; Tomy - Pardede, 2018; Smitt, 2018, Reis, 2011 etc.), while a business model can be seen as a form how the start-up seeks to offer a value for customers and transform it into firm's revenues [12-16]. From this point of view, the start-up is perceived as "a 
business solution for social problems" [17] that is repeatable and scalable. From the perspective of the cycle of financing, the start-up is mainly considered the firm before private equity capitalists participate in financing, before the acquisition, eventually before the IPO that we de facto consider the "highest" form of the start-up's financing. However, the strict definition of qualitative and quantitative start-up features is absent in practice.

In Slovakia, the legal definition of start-up points to the formal aspect of this term. Following the article 1, paragraph 2g) of the Act No. 290/2016 Coll. on Support of Small and Medium Enterprises and on the Amendment and Supplements to the Act No. 71/2013 Coll. on the provision of subsidies within the competence of the Ministry of Economy of the Slovak Republic as amended, the start-up is: a commercial company that is obliged to create a registered capital; it has a registered office in the Slovak Republic; since its establishment has not expired more than 36 months; it is controlled by natural persons, who are its founders; it is an innovative enterprise, microenterprise, small or medium enterprise. The importance of such kind enterprises for the Slovak economy is more emphasized in the broader definition found in the document Concept for Start-up Support and Start-up Ecosystem Development in the Slovak Republic (2015). Following it, the start-up is an entrepreneurial initiative with high growth and innovation potential that can kick-start and long-term promote smart and inclusive economic growth and attract foreign investment. It contributes to the development of sectors with high value added, regional and global competitiveness and employment creation of skilled labour.

\section{General approaches to business valuation}

Knowing the value of any firm is given by reasons determined by internal and external needs of the firm. In the case of a start-up, the valuation is a central matter to both investors and owners and understanding critical aspects of valuation by both sides is a precondition of positive, productive relationships between them. The value of a start-up is an indicator of investment opportunity and determinant of the size of a part of own equity "exchanged" for external equity. The general problems in valuation of a start-up [2, 18, 19]:

- no or limited financial and accounting history, which is irrelevant to estimate future development (typical mainly for idea and seed stage of start-up development),

- low or zero sales and earnings,

- dependence on own capital with an impact on the costs of capital,

- $\quad$ high probability of the start-up failure that makes difficult investors to apply going concern principle in valuating,

- relatively low liquidity of capital share in the start-up firm,

- $\quad$ uniqueness of the start-up in the context of its comparison with other firms,

- most assets are intangible.

The valuation of a start-up in the earliest stages of development, generally focus more on the quality of the management and less on the amount of the valuations. The lack of information necessary for "standard" valuation is compensated mainly with additional information on the person of an entrepreneur and business project [19]. For follow-on and later stage investing, the range of valuations is much wider and the number and complexity of valuation equations much greater [20]. There is no consensus about the classification of valuation approaches, neither valuation approaches of start-ups. For the purpose of this article, we followed the classification of Engel (2003) - he divides the valuation methods into classical and special valuation methods that better fit conditions and specifics of startup firms. The first group includes methods based on asset approach, income approach, and market approach, the second group includes except other real option approach, goodwill method, first Chicago method, venture capital method, risk factor summation method, 
scorecard method and Berkus method. The last three options of start-up valuation are presented in the text bellow.

\subsection{Berkus method (rule of thumb)}

The origin of the method is the mid of 1990's and in 2001 the method was officially published in the well-known "bible" "Winning Angels" for venture investors (in general meaning) written by Amis - Stevenson. The model was created in conditions of U.S. market and mostly addressed for early stage pre-revenue technology start-ups. Berkus built up the model on his own findings and experience that lengthy revenue forecasts rarely turned out to be accurate. In 2016, the model was reconstructed, but its main idea - to bridge chosen qualitative criteria typical for the start-up and relating to the primary risk areas with their quantitative (monetary) expression, has not changed. Based on the model, each valuation area and the associated risks - sound idea (product risk), prototype (technology risk), strategic relationship (marketing risk), management team (execution risk), and product rollout and sales (production risk), add the value of $\$ 0.5$ million, while the final value of the start-up ranges between 0 and $\$ 2.5$ million. The method is relatively subjective, but on the other hand flexible as it allows investors to negotiate or create a maximum valuation they are willing to accept in a perfect situation. The flexibility of values is important because mainly due to obviously existing differences between countries, and regions, the investment potential of investors may differ. It may differ also depending on a type of start-up.

\subsection{Risk factor summation method}

Like the Berkus method, the risk factor summation method is suitable valuation for prerevenues start-ups in the early stages of development. The valuation is based on the comparison with a comparable start-up in the region that is used to derive an initial value of a valued start-up (average pre-money value) and risk factors inherent to firm. The main aim of the method is to force an investor to think about various types of risk involved in a specific start-up and manage them in meeting a reasonable exit value within the scheduled period. The risks, which each has a monetary value depending on its size, are divided into 12 areas: management, stage of business, legislation \& politics, manufacturing, sales \& marketing, funding, completion, technology, litigation, internationality, reputation, and potential lucrative exit. The management risk is considered the major risk factor and needs the largest amount of time to scrutinize. The value of a start-up is developing according to three types of scenarios - positive (+), neutral ( 0 or "“-") and negative (-). In case of both positive and negative scenario, it is considered with two level risk strength $(+1,+2 ;-1,-2)$. Each risk factor is able to change the initial value of the start-up by $\$ 250,000$ depending on the scenario and level risk. Similar to Berkus method, it shows the signs of subjective evaluation, but is obvious the perception of risks is more precise. Its advantage and disadvantage is the fact that the method is market-oriented. Determination of the average pre-money value of a start-up mirrors the situation in region. On the other hand, the problem can be the shortage of information relating to the region to derive this value.

\subsection{Scorecard valuation method (Bill Payne Method)}

The value of a start-up results from the benchmark with comparable start-ups in the industry and region. The starting points is to derive the average start-up value to establish a pre-money valuation of a target start-up. Pre-money valuation varies with the economy and with the competitive environment for start-ups within a region. (Payne, 2011) Subsequently, selected criteria are evaluated, which point to the value potential of a start-up 
based on comparison with similar start-ups in the region. It can only be made for firms at the same stage of development. Each criterion (comparison factor) ranges in a given margin, wherein management and market opportunity are ranked as the most important $(0-$ $30 \% ; 0-25 \%$ ). The criteria cover several areas (management, market opportunity, product and technology, competitive environment, marketing, sales and partnerships, need for additional founding, other), and the methodology gives an opportunity to an evaluator to include other reasonable factors. The final value of a target start-up is a multiply of the sum of factors and the average start-up's value.

\section{Conclusion}

The presented article is mainly a theoretical discussion about the issue of start-up valuation. The author focused mainly on valuation methods that are suitable for start-up valuation in the earliest stages of a start-up development, namely Berkus method, Risk factor summation method, and Scorecard valuation method. From the analysis of current situation in the area of start-up valuation follows that valuating of pre-revenues firms is the most difficult, since in valuing are presents problems such as: no or limited financial and accounting history, low or zero sales and earnings, dependence on owners' capital with an impact on the costs of capital, high probability of failure that makes difficult investors to apply going concern principle in valuating, relatively low liquidity of capital share, uniqueness of a start-up in the context of its comparison with other firms, and fact that most assets are intangible. Thereby it is obvious, that is not possible to apply a "general" valuation approach to start-up valuation, since a start-up is characterized by the unique on the one hand and uncertainty on the other.

\section{References}

1. K. Kramarova, E. Kicova, Použitie reálnych opcií ako metódy hodnotenia projektov v rámci investičnej činnosti podniku. Grant journal, 3, 37-41 (2014)

2. A, Damadaran, Investment Valuation. 2nd edition. (NY: John Wiley \& Sons, 2002)

3. CBInsights, The Top 20 Reasons Startups Fail. Available at: https://www.cbinsights.com/research/startup-failure-reasons-top/ (2018).

4. D. Hechavarría, C. Matthews, P. Reynolds, Does start-up financing influence start-up speed? Evidence from the panel study of entrepreneurial dynamics. Small Business Economics, 46, 137-167 (2016)

5. V. Fried, R. Hisrich, Toward A Model of Venture Capital Investment Decision Making. Financial Management, 23, 28-37 (1994)

6. Paul, S., G. Whittam, and J. Wyper, Towards A Model of the Business Angel Investment Process, Venture Capital, 9, 107-125, (2007)

7. M. Van Osnabrugge, R. J. Robinson, Angel Investing: Matching Start-up Funds with Start-up Companies: The Guide for Entrepreneurs, Individual Investors, and Venture Capitalist, (Jossey-Bass, San Francisco, 2000)

8. M. Zinecker, J. Rajchlová, Private equity and venture capitalists' investment criteria in the Czech Republic. Acta Universitatis Agriculturae et Silviculturae Mendelianae Brunensis, 68, 641-652 (2010)

9. M. Van Osnabrugge, R. J. Robinson, Angel Investing: Matching Start-up Funds with Start-up Companies: The Guide for Entrepreneurs, Individual Investors, and Venture Capitalist, (Jossey-Bass, San Francisco, 2000) 
10. R. Sudek, Angel Investment Criteria, Journal of Small Business Strategy, 17, 89-103 (2006)

11. RÚZ, Analýza podmienok zakladania podnikov z hl'adiska start-upov ako potenciálu zvýšenia zamestnanosti na Slovensku. Available at: ruzsr.sk/app/webroot/.../files/RUZ_FINAL_Analyza_startupy.pdf, (2017)

12. V. H. Peemöller, T. Geiger, H. Barchet, Bewertung von Early-StageInvestment im Rahmen der Venture Capital Finanzierung, Finanz Betrieb, 5, 334-344 (2001)

13. S. Blank, B. Dorf, The Startup Owner's Manual: The Step-By-Step Guide for Building a Great Company (Pescadero: K\&S Ranch, 2012)

14. S. Tomy, E. Pardede, From Uncertainties to Successful Start Ups: A Data Analytic Approach to Predict Success in Technological Entrepreneurship. Sustainability, 10, 124 (2018).

15. A. Schmitt, A Dynamic Model of Entrepreneurial Uncertainty and Business Opportunity Identification: Exploration as a Mediator and Entrepreneurial SelfEfficacy as a Moderator. Entrepreneurship Theory and Practice, 42, 835-859 (2018)

16. E. Ries, The Lean Startup: How Today's Entrepreneurs Use Continuous Innovation to Create Radically Successful Business, (Crown Business, New York, 2011)

17. F. B. De Oliveira, L. P. Zotes, Valuation methodologies for business startups: A BIBLIOGRAPHICAL STUDY AND SURVEY. Brazilian Journal of Operations \& Production Management, 15, 96-111 (2018)

18. J. Bukoven, Problémy oceňovania Startupov v súčasnosti. Časopis znalostní společnosti, 4, 61-69 (2016)

19. M. Skalicka Dusatkova, M. Zinecker, Valuing start-ups - selected approaches and their modification based on external factors. Business: Theory and Practice, 17, 335-344 (2016)

20. E. M. Kauffman, Foundation Valuaing pre-revenue companies, Available at: https://www.angelcapitalassociation.org/data/Documents/Resources/AngelCapitalEduc ation/ACEF_-_Valuing_Pre-revenue_Companies.pdf, (2007)

21. D. Rahardjo, Sugiarto: Valuation model using a mixed real options method: a review on Singapore and Indonesia digital startups. Advances in Social Science, Education and Humanities Research, 308, 9-12 (2019) 